\title{
Rumpelstiltsken's feat: cloth and German trade with Iceland
}

\author{
MICHÈLE HAYEUR SMITH
}

Hayeur Smith, M. 2019. Rumpelstiltsken's feat: cloth and German trade with Iceland. AmS-Skrifter 27, 107-120, Stavanger, ISSN 0800-0816, ISBN 978-82-7760-183-0.

\begin{abstract}
Identifying foreign cloth imports in the Icelandic archaeological corpus is difficult at best, yet given widespread similarities in homespun cloth from sites across the country, imported cloth can be identified visually through the presence of refined finishing techniques (such as teaseling, shearing, and fulling) that were uncommon in Iceland and were the products of specialist craftsmen in Europe. This paper examines textile assemblages from deposits datable to the period of Hanseatic trade at three sites, Gilsbakki, Reykholt, and Stóra-Borg that represent two wealthy, interior, parish centres and a moderate-sized coastal farm, respectively. Variations in the number and diversity of imported cloth items within these sites' assemblages suggest that while Hanseatic material culture was widely spread on Icelandic rural sites, the nature of the material culture sub-assemblages attributable to Hanseatic trade was not obviously a direct function of households' wealth or proximity to harbours but may have engaged other cultural factors linked to the political and social challenges of the post-Reformation period and the roles of individual households in regional or intra-Icelandic trade.
\end{abstract}

Michèle Hayeur Smith, Haffenreffer Museum of Anthropology, Brown University, Box 1965, PROVIDENCE, RI 02912, USA.

E-mail: michele_smith@brown.edu

Keywords: Hanse, cloth import, trade, English cloth, Icelandic cloth

Hanseatic merchants arrived in Iceland and began to exert a strong presence there between c. 1430-40. ${ }^{1}$ Despite attempts by the Danish crown to curb their economic activities, their trade and influence expanded across the island until 1602 when the Danish monarchy restricted trade with Iceland to companies operating under direct and monopolistic royal authority. $^{2}$ The Hanseatic expansion into the North Atlantic came at the tail end of Hanseatic activity, which began with a boom in the trade of the cities of the Hanse around the Baltic a few centuries earlier. During this period, German merchants controlled much of that region's economy and, currently, analysis of the material evidence for this short-lived episode of German trade has been a topic of growing interest among archaeologists working in the North Atlantic. ${ }^{3}$ Analyses and research are underway to identify harbours, excavate trading sites, and delineate the material culture of this phenomenon and its impact on the communities of the North Atlantic region.

Documentary sources indicate that textiles were among the commodities imported to the North
Atlantic by Hanseatic merchants. Conversely, Icelandic households are known to have produced and traded woollen cloth that was exported to continental Europe. Tracing the movements of these textiles, in both directions, presents considerably greater challenges than monitoring the movement of some other elements of Hanseatic material culture, such as ceramics or glass, due to the lack of comprehensive published information on Icelandic archaeological textiles. Until recently, textile analyses in Iceland were carried out largely by the late Else Guðjónsson, who devoted most of her research efforts to the study of finer textiles, ecclesiastic items, tapestries, and ethnographic items related to the evolution of the Icelandic national costume. ${ }^{4}$ A selected few papers have been devoted to Iceland's archaeological textile remains, yet the majority of the archaeological textiles recovered from excavations over the past century have remained understudied, although they are abundant, with between four thousand and six thousand fragments surviving. ${ }^{5}$

Current research by this author on Icelandic and North Atlantic archaeological textile collections 
seeks to overcome this gap while exploring a series of inter-related topics in which textiles play a significant role. ${ }^{6}$ As the Hanse were notorious for their efforts to control the textile trade in Europe, moving cloth from one location to another in various stages of production, the question must be raised: what was the impact of this Hanseatic textile trade on Iceland? Further, why would Icelanders have felt the need to import more woollens, or other textiles, when they produced enough cloth to clothe their own population and generated sufficient surpluses for foreign trade? At the same time, this local homespun gained value as a unit of currency within Iceland, throughout the Middle Ages, ${ }^{7}$ and was used as a form of payment for compensation in legal transactions, for paying tithes and taxes, to settle fines, and as a medium for internal trade and export. It was also used, of course, for the household production of clothing, tents, sails, furnishings and farm items. ${ }^{8}$

Identifying Hanseatic cloth imports into Iceland, or the movement of Icelandic textiles into Hanseatic ports, are not easy tasks without the use of isotopic analyses of the wool itself, which might provide opportunities to source the origins of the primary raw materials. Some of this isotopic work has begun as a pilot project with three samples that could apply to the period under discussion while the others are later (see below). Nevertheless, this paper will attempt to review and identify some Hanseatic cloth imports into Iceland using data from three sites from the late fifteenth to seventeenth centuries: Stóra-Borg, a wealthy coastal farm in southern Iceland, and Reykholt and Gilsbakki, both of which are elite residential sites and parish centres located in the interior of western Iceland. These three sites were chosen, as they all offered significant numbers of textiles with recent and reliable Accelerator Mass Spectrometry (AMS) dates and data on textiles from the Hanseatic period in Iceland. These results and insights must be preliminary for the time being, with analyses based more on visual and comparative recognition with known local cloth types.

\section{Identifying foreign cloth: the cloth of Hanse - problems and impediments}

Mehler identified two types of Hanseatic material culture coming into Iceland during the late fifteenth to the seventeenth centuries: on the one hand artefacts produced in the Hanse core area by craftsmen work- ing in the area of present-day Germany and delivering their goods to Hanseatic merchants for further sale, or in one of their Kontors that can be described as Hanseatic, presuming their provenance can be identified; ${ }^{9}$ and, on the other hand, artefacts made from non-indigenous raw materials or by foreign craftsmen working outside areas of Hanseatic influence, but transported by the Hanse. ${ }^{10}$ In addition to these, a third category of material culture found in Icelandic sites of this time consists of items that came to Iceland via trade with ships of other nationalities, such as English, Spanish, Basque, and Dutch whalers or fishermen and non-Hanseatic German tradesmen stocking up in Iceland and exchanging their wares for Icelandic foodstuffs, fresh water, or goods that could be resold in England or Europe as secondary products of their voyages. ${ }^{11}$

Prior to the Hanseatic presence in Iceland, English merchants had conducted trade in this region for some time. ${ }^{12}$ In 1490, however, the Danish-Norwegian state granted foreign merchants, including those from German and Baltic ports, licences to trade with the Faroes and Iceland. ${ }^{13}$ This presented a new set of challenges for the English, and between 1486 and 1532 they suffered increasingly in violent clashes with German merchants. ${ }^{14}$

Archaeologically, the role of these foreign traders is apparent through the presence of imported material culture in sites and deposits from these centuries, but trying to tease out who brought what is not. The types of cloth carried in the holds of Hanseatic merchants' ships for trade with North Atlantic communities was diverse and included wares made in England, Holland, and elsewhere in northern Europe, as they had become textile suppliers and trans-shippers for much of Europe. ${ }^{15}$ Kijavainen states, regarding trade goods in Finland, that cloth was sent directly to Hanseatic towns such Reval, Lübeck and Danzig before reaching Turku. ${ }^{16}$ Munro and Maik have both documented English cloth - specifically English woollen broadcloth and Kerseys - circulating abundantly in areas of Germany controlled by the Hanse, as well as in central and eastern Europe during the late fifteenth century. ${ }^{17}$

English cloth itself was frequently the product of complex and non-linear production processes; it could be woven in one location and sent elsewhere for finishing treatments, such as dying, fulling, teaseling, and so on. ${ }^{18}$ Documentary evidence even suggests that Icelandic wadmal imported to England was frequently sent out for such secondary treatments before it was resold to English or more distant consumers ${ }^{19}$. 
Despite these complexities, Penelope Walton Rogers in pioneering research, argued that visibly identifiable English cloth was present in Icelandic textile collections from excavated late-medieval and post-medieval deposits of the elite interior farmstead of Reykholt. ${ }^{20}$ Her insights suggested that the potential existed for making broader inferences about the role of foreign trade in textiles within Iceland, but were limited by the scale of the collections. The absence of comparative data from across Iceland also limited the potential for assessing the significance of variability within the corpus from Reykholt.

\section{Recognizing indigenous Icelandic textiles and identifying anomalies as imports}

\section{Textile analysis of Icelandic collections}

The Icelandic corpus of archaeological textiles is substantial with numbers ranging between eight thousand to ten thousand fragments of cloth with approximately thirty-eight sites analysed at the present time. As mentioned above, these collections have escaped the scrutiny of textile analysts and historians and never been subjected to a systematic analysis, prior to the author's textile projects. ${ }^{21}$

The analysis of these textiles was carried out from 2010 to the present, at the collections centre of the National Museum of Iceland (Pjóðminjasafn Íslands), where they are curated. Each piece was analysed for fibre identification, object dimensions, thread count, warp and weft yarn dimensions, spin tension (when possible), construction details, colour, weave pattern, evidence for incorporation within larger garments or objects, adhering or incorporated non-textile materials, and unique features. All objects were photographed using a digital DinoScope ${ }^{\mathrm{TM}}$ microscope with magnifications ranging from $70 \mathrm{X}-200 \mathrm{X}$ and a Nikon digital camera. Samples were taken from selected pieces of cloth and were tested for dye and fibre identification by Margaret Ordoñez at the University of Rhode Island's Department of Textile Conservation, ${ }^{22}$ and by McCrone's Inc, Ill. USA. Many pieces were sub-samples for AMS dating (approximately thirty-four for Iceland alone). More recent analyses have included a pilot project using strontium isotopic analysis as well as aDNA conducted at the National Museum of Denmark, and the Natural History Museum of Denmark. aDNA carried out by Mikkel Sinding proved to be problematic on samples resulting from older excavations that had been curated many decades ago. Many of these were contaminated, while permafrost sites produced the most successful results. ${ }^{23}$ Strontium isotopic work carried out by Karen Frei on seventeen samples of Icelandic textiles from the Viking Age to the early modern period resulted in five of the seventeen samples of non-local provenance having all values $>{ }^{87} \mathrm{Sr} /{ }^{86} \mathrm{Sr}=0.7092 .{ }^{24}$ The textiles of non local provenance were identified in the late medieval and early modern textiles from the sites of Alpingisreitur, Skálholt and Aðalstræti. Three from Alpingisreitur could be applicable to the discussion of Hanseatic cloth as they date between 1500-1800. ${ }^{25}$ All qualitative and quantitative data discussed in this paper result from these analyses, unless otherwise noted.

How does one recognize non-Icelandic cloth types archaeologically, or cloth types that are referred to in written sources? Maik felt that the weaving techniques used in western and central Europe were so similar that it was very difficult to identify textile imports visually in collections. ${ }^{26}$ Swatches attached to pattern cards, letters, and contracts are useful aids, when available but in cultures such as medieval Iceland's, with nonindustrialized textile traditions, these aids are non-existent. However, in Iceland legal documents, medieval exchange lists, and other literary sources provide clues to the types of cloth - indigenous and imported - that circulated or were recognized as economically significant from approximately the late twelfth century onward. These documents provide clues to the kinds of textiles that might be found archaeologically, but not on their ubiquity or even frequency in use, let alone their representation in the archaeological record. Nor can it be assumed that these sources refer to all of the textile types manufactured in Iceland or imported to the country, as the number of such references is relatively small and the agendas behind their creation are quite different and frequently obscure.

Against these limitations of the documentary record, an impressive and growing corpus of analysed textiles, textile fragments, and weaving debris from farm sites across the country provides strong evidence for the range of textiles produced in Iceland, their diagnostic attributes, characteristics of the wool produced by Icelandic sheep, and changes through time in all of these variables. ${ }^{27}$ Minar argues that in pre-industrial contexts weaving tends to be very conservative, with changes occurring very slowly over time. ${ }^{28}$ Overall, the Icelandic corpus supports this assertion, with changes building incrementally upon existing traditions and practices for preparing wool, spinning thread, weaving textiles, and constructing objects from them. ${ }^{29}$ The 


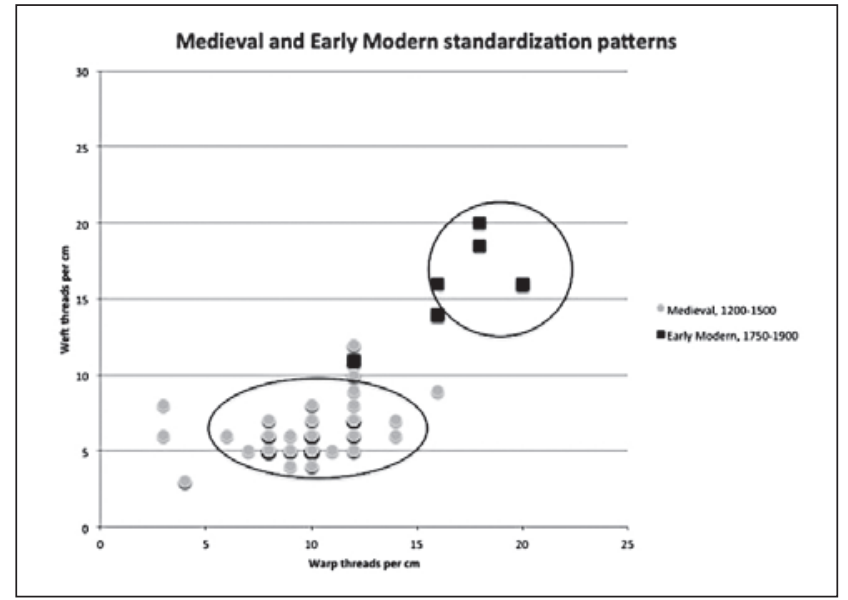

Fig. 1. Medieval and early modern standardization patterns (Hayeur Smith 2014a).

author's analyses of assemblages from across Iceland suggest very little regional differentiation of weaving styles within Iceland and considerable uniformity in the composition of textile assemblages across the island. When they happen, major changes in assemblage composition or in the introduction of new textile manufacturing strategies, such as the appearance of knitting or the use of plied yarn in weaving homespun, also appear to happen nearly concurrently across the country. Given these similarities and their predictable patterning, the presence of unusual elements, differences in materials or surface treatments, or unusual

Table 1. Domestic Icelandic homespun and woollens (continued to be produced in less abundant quantities up until the nineteenth century) compared to possible imports based on the analysis of Icelandic archaeological textile collections (Hayeur Smith 2012a; Hayeur Smith 2012b; Hayeur Smith 2013; Hayeur Smith 2014a; Hayeur Smith 2014b; Hayeur Smith 2015; Hayeur Smith 2016).

\begin{tabular}{|l|l|}
\hline \multicolumn{2}{|c|}{$\begin{array}{c}\text { Domestic homespun presents in a specific manner, and the presence of } \\
\text { different weaving strategies can indicate foreign imports }\end{array}$} \\
\hline \begin{tabular}{l} 
Icelandic homespun from $11^{\text {th }} \mathrm{c}-19^{\text {th }} \mathrm{c}$. \\
\hline $\begin{array}{l}\text { Weaves not balanced } \\
\text { Wwills predominate and fewer tabbies }\end{array}$
\end{tabular} & $\begin{array}{l}\text { Tabbies, felts, } 2 / 1 \text { twills } \\
\text { Even and balanced weave }\end{array}$ \\
\hline $\begin{array}{l}\text { z/s spun (z-warp-s weft) in early modern } \\
\text { period this becomes z2s/s }\end{array}$ & Predominance of $s / \mathrm{s}$ some $z / \mathrm{s}$ \\
\hline Greater number of warp yarns than weft & $\begin{array}{l}\text { Balanced with equal number of warp and weft } \\
\text { yarns (11x11) }\end{array}$ \\
\hline Seeming lack of dyes & $\begin{array}{l}\text { Frequent evidence of dyes- red (madder) and } \\
\text { some blue (indigotin/ woad) }\end{array}$ \\
\hline Some surface treatment but not consistent & $\begin{array}{l}\text { Heavy surface treatment fulling treaselling, and } \\
\text { shearing on one or both sides. }\end{array}$ \\
\hline $\begin{array}{l}\text { Wool: coarse warp yarns and fine fluffy wefts } \\
\text { (Icelandic dual coated sheep) }\end{array}$ & Fine wool, or unusual fibers, linen, silk \\
\hline
\end{tabular}

weaves in a site's assemblage may suggest the presence of foreign intruders in the mix. However, identifying foreign cloth visually in any site's assemblage requires a good knowledge of indigenous collections and textile traditions.

From the early to late medieval period (c. 10601600), as described above, Icelandic homespun was used as a form of currency. As late as the eighteenth century and even continuing into the late nineteenth century (in a much more sparse fashion) nearly all of Iceland's homespun textiles were produced in all - or nearly all - farms across Iceland on the warpweighted loom, using threads spun with a high top or drop spindle. ${ }^{30}$ While there is no evidence in either documentary sources or the archaeological record for centralized workshops, and neither archaeological nor documentary sources support the idea that textile production was in the hands of elites or undertaken as a specialist industry. However, these textiles' qualities were legally regulated due to their use as a form of commodity currency. ${ }^{31}$ As a result, many attributes of Icelandic homespun textiles spin direction and thread counts, panel widths and units of measurement - were standardized to facilitate intra-Icelandic exchange and foreign trade (see Fig. 1. for standardization of thread counts suggesting production of cloth as currency in medieval Iceland compared to textiles from the early modern period). These patterns of standardization appear to be particularly tight from the late eleventh to the late sixteenth century, the period when cloth was most heavily used as currency. Throughout this period, textiles from all farm sites examined were produced in nearly identical ways, with a comparable and highly restricted range of thread counts and weaves. Assemblages from farm sites across the country, both before and after this interval, are more diverse and suggest the creation and use of a wider range of textiles that were responses to the domestic needs of individual households rather than market demands or legal requirements. All or most of these sites produce examples of weaving errors, starting bands, off-cuts, spun and unspun yarn and other technological artefacts such as spindle whorls and loom weights that demonstrate that cloth was made at these farms, not just consumed there. Until European 'flat looms' or treadle looms were introduced to Iceland during the early eighteenth century, all weaving was carried out by women with taboos possibly restraining men's involvement in textile work. ${ }^{32}$ Furthermore, as there is no evidence for craft specialization in Iceland's tex- 
tile economy (no fullers, no dyers, nor shearers), all of the steps required to produce cloth were undertaken on individual farms.

Macroscopic and microscopic analyses of Icelandic archaeological collections have demonstrated that $99 \%$ of Icelandic homespun was used both as currency convertible in commercial transactions and also for domestic uses. It was made of wool, with $2 / 2$ twills dominating all assemblages despite the presence of other weave types. Warp yarns were hard-spun and ztwisted, while weft yarns were soft-spun and s-twisted. This difference in the yarns of each system stems from the nature of the wool found on the Icelandic dualcoated sheep, which included both a coarser and longer outer layer of wool (the tog), used preferentially for the weight-bearing warp threads, and a lighter, shorter, and fluffier under-wool (the pel), which was normally used for wefts. Warp yarns tended to outnumber weft yarns by a factor of two-three to one, and thread counts in the forms of cloth that were legally regulated ranged between 5-12 warp yarns per centimetre and 4-8 weft yarns per centimetre, with repeated combinations of warp and weft numbers reflecting different grades of cloth within the general category known as wadmal (vaðmál), literally 'standardized' or 'measured' cloth. ${ }^{33}$ This cloth type dominates all assemblages after $c .1100$ and was produced on farms of all types across Iceland until the late sixteenth century. ${ }^{34}$

Silks, velvets, or fine textile types, such as worsted twills and cloth woven with finer fleeces, suggest imported cloth from the mainland and contrast remarkably clearly with indigenous textiles in Icelandic collections. Far more abundant however, are the finely woven tabbies often with visible finishing that occur frequently in collections and are also of probable foreign origin. These are finely woven, made of softer fleeces, have very high-thread counts, and are frequently dyed red. Occasionally, they are spun differently than Icelandic cloth and are s-spun in both warp and weft systems. In fact the late medieval and early modern samples from the sites of Alpingisreitur, Skálholt and Aðalstraeti presenting with these same characteristics have all been confirmed by isotopic analysis as non-local, suggesting that the earlier ones in the Icelandic corpus probably are as well. In Table 1 these elements are listed and compared to Icelandic homespun from the eleventh to the nineteenth century. Several of these types of cloth were identified in the collections from Reykholt, Stóra-Borg, and Gilsbakki and will be discussed along with other possible cloth imports identified at these sites.

\section{Foreign cloth from Stóra-Borg, Gilsbakki and Reykholt and discussion}

\section{Stóra-Borg}

Stóra-Borg was a middle-ranked farm site located on the southern coast of Iceland that was abandoned in 1834 due to coastal erosion. ${ }^{35}$ Rescue excavations were carried out from 1978-1981 by Mjöll Snæsdóttir as the site was being destroyed through the encroachment of a meandering river channel. The large and exceptionally complex, tell-like farm mound incorporated the remains of at least four major, superimposed farm complexes and seventeen building phases representing rebuilding episodes within a continuous occupation that spanned at least 800 years, from the early medieval period (perhaps as early as the tenth century) through the early historic period. The final report for this important site is currently under completion.

The textile collections from Stóra-Borg are substantial, with roughly 700 recorded find numbers and nearly twice as many fragments of cloth. The analysis of this collection is not yet complete, but nearly half the assemblage has been analysed.

The phasing of this site, and the dating of its phases, have been slightly problematic due to the scale of the site itself and the context of its excavation. Given the rapid pace of erosion, priorities during each year of the excavation had to be based on the shifting locations of the erosion fronts, rather than on a more structured expansion of previous years' excavation units. With losses to erosion and discontinuities, the general structure of the phasing is clear but links between deposits and their dating are still being assessed. AMS dates carried out on textile fragments as part of this project (see Fig. 2) have helped to clarify some of these questions and confirmed that Phases $2 / 3,3$, and the earliest parts of Phase 2 represent the centuries during which Hanseatic commercial activity was most active in Iceland.

At a site such as Stóra-Borg, located on the southern coast where fishing was actively pursued and a trade in locally produced dried fish supported most farms, it might be expected that the Hanse presence would have been felt through direct or indirect trade. As expected, several of the finely woven, and probable imported tabbies described above were identified within the collection.

The majority of imported textiles from the late fifteenth- to early seventeenth-century deposits are from Phases 2 and 3. Phase 2 (Fig. 3) is dominated by 


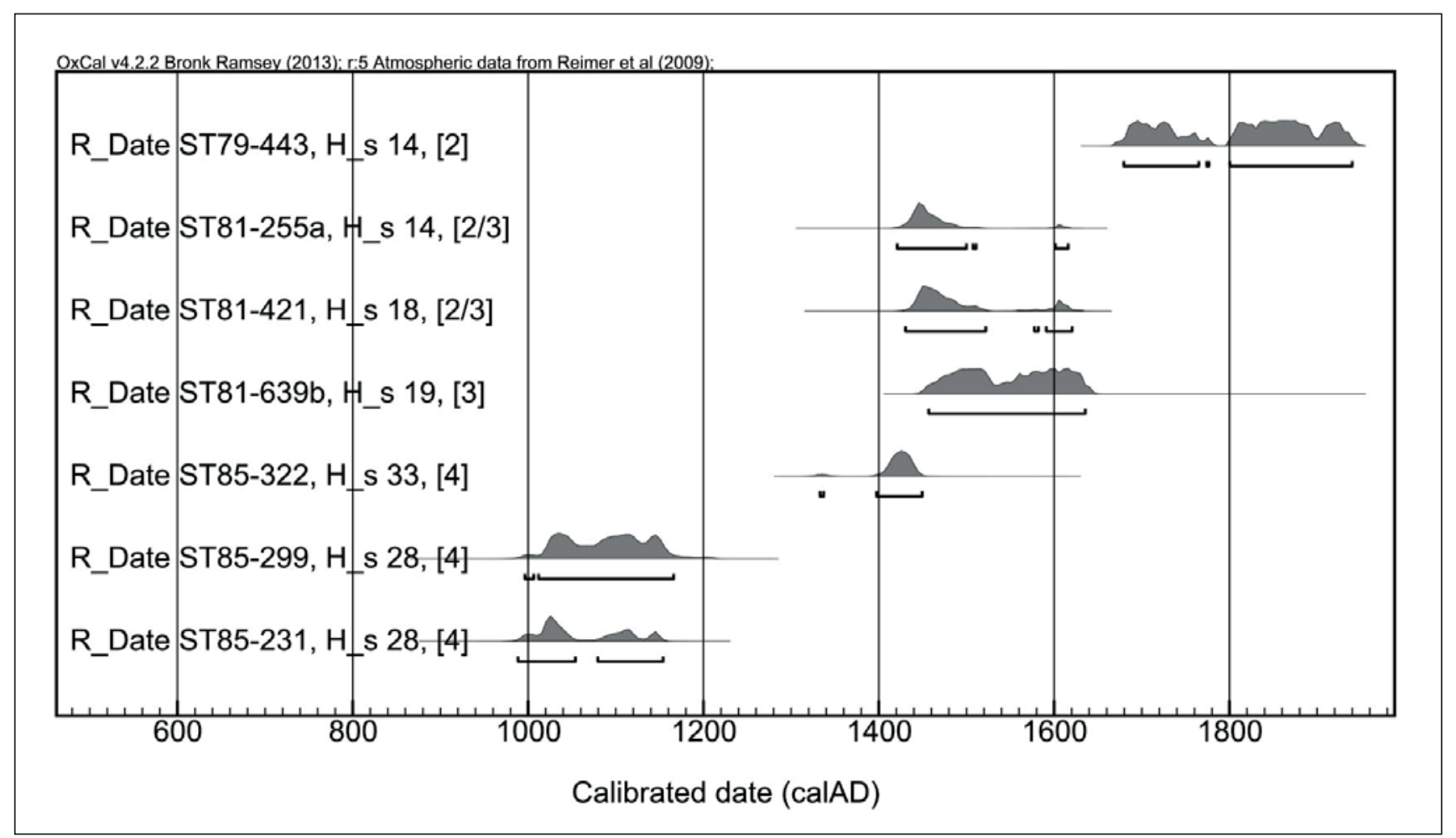

Fig. 2. Calibrated AMS dates on textiles sampled from Stóra-Borg (illustration: Kevin P. Smith).

the remains of nine attached houses or rooms forming a large turf house complex of typical southern Icelandic type. This was initially thought to date between c. 1600-1700 36 and AMS dates carried out on textiles from its deposits confirmed this, with dates spanning c. 1600-1750. From this phase textiles were found in rooms 14 and 9. Phase 3, underlying the Phase 2 farm, consist of deposits and architectural units beneath Phase 2 that represent an earlier range of turf-walled buildings laid out in similar orientation to the overlying Phase 3 farmhouse. Continuously accreting deposits between rooms in the Phase 2 and 3 farms and similarity in the placement of the farms' walls and rooms, strongly suggest that Phase 3 represents a major rebuilding of the Phase 2 farm, while the intervening 'Phase $2 / 3$ ' deposits represent repairs and floor accretions between the initial construction of the Phase 2 houses and the Phase 3 rebuild. Artefact types, tephra, and stratigraphic considerations suggested that Phases $2 / 3$ and 3 were dated to the period c. 1500-1600, while AMS dates on textiles suggest that these layers span a slightly longer and earlier range, c. 1450-1600. Textiles in Phase 3 were found in house 18 (Fig. 4).

Textiles, both locally made and foreign imports are clearly concentrated in the same part of these superimposed houses, suggesting continuity in the activities undertaken within these rooms over a period of nearly two hundred years and perhaps that this may have been a stofa, or work room, in which women produced and worked upon textiles, along with other manufacturing activities.

At Stóra-Borg, 33 items out of 300 analysed fragments appear to be possible imports displaying the characteristics described above, separating them clearly from more typical Icelandic homespun textiles. Many of these were tabbies spun and woven differently from their Icelandic counterparts, or made with much finer wools or other exotic materials, including silk (Fig. 5). Many appear to have been dyed red and in some cases teaseled and sheared - the work of specialized craftsmen in Europe. ${ }^{37}$ The tabbies described here compare well with foreign woollen imports and material evidence for Hanseatic trade items identified in eastern Europe by Maik and others. ${ }^{38}$

\section{Reykholt}

Reykholt, best known as the farm of Snorri Sturluson during the thirteenth century, is located in the western interior of Iceland, approximately 40 kilometres from the coast. Reykholt was an elite ecclesiastic centre throughout the medieval and post-medieval periods ${ }^{39}$ which eclipsed its early medieval rival Gilsbakki in regional affairs during the early modern period. Excavations of the farm and its church were undertaken by Guðrún Sveinbjarnardóttir over a span of 20 years, 

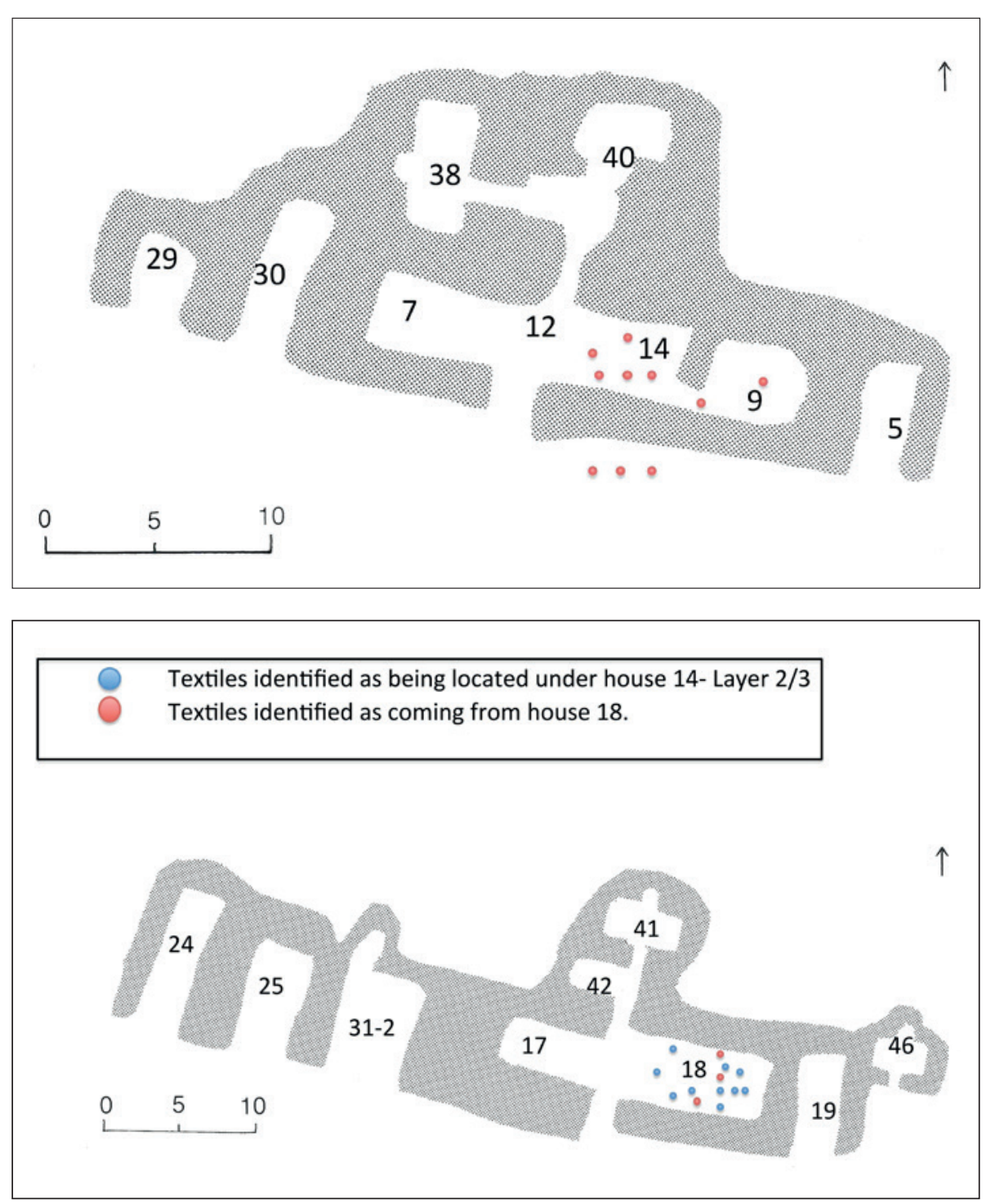

Fig. 3. Phase 2 at Stóra-Borg thought initially to date between c. 1600-1700, with house numbers listed. Following AMS dating of select textile fragments this phase dates to c. 1600-1750 (from Sncesdóttir 1991).

Fig. 4. Stóra-Borg Phase 3 said to be dated between c. 15001600. Following AMS dating of selected textile fragments, c. 1450-1600. Furthermore, for material that was located in the floors of house 14 Phase 2, these were identified as Phase 2/3: c. 1450-1500/1550 suggesting that some material found in Phase 2 may stem from Phase 3 and that delineating the boundaries between these layers may have been difficult (from Sncesdóttir 1991).
1987-2007. The textiles from the farm were analysed by Penelope Walton Rogers, ${ }^{40}$ while the textiles recovered during the excavation of the church have been analysed by the author and were published as a specialist report in 2016.

The assemblage from Reykholt is considerable, including 340 fragments from the excavation of the farm mound and 408 from the church excavation. ${ }^{41}$ Imported textiles were identified in the farm mound's Phase 4 (sixteenth-to seventeenth-century) and early Phase 5 (seventeenth-to nineteenth-century) deposits.

Despite near contemporaneity with the textile assemblage from Stóra-Borg, Walton Roger's classification of foreign cloth in these phases suggests an assemblage somewhat different, including worsted twills (both $2 / 2$ and $2 / 1$ twills) with a satin-like finish that are said to have originated in northern Germany and that spread across Europe in the fourteenth century, remaining popular for centuries thereafter. ${ }^{42}$ In addi- ion to these, the farm mound produced silks from the Eria and Atlas silk moths, felts said to be from either Flanders or England, and lastly finely woven tabbies. ${ }^{43}$

The church excavations have a slightly different phasing, with imported textiles most common in Phases 3 (fourteenth to sixteenth century) and 4 (sixteenth century to 1886). Foreign imports were far less numerous in the excavated deposits from the church, presumably because most of the site's textile work, including sewing and the making of textile items from both local and foreign cloth, took place within the farm rather than in the church. Worsted twills and silks were both identified in the assemblage from the church, although from much later phases, while fine tabbies dominated the foreign cloth assemblage from the period of Hanseatic trade. Overall, the assemblage of imported cloth from Reykholt displayed greater variety and more luxury items, while imports at Stóra-Borg were of a more utilitarian nature. 


\section{Gilsbakki}

Gilsbakki is located $15 \mathrm{~km}$ east of Reykholt, and was a powerful chieftains' centre from the Viking Age until the early thirteenth century when it was absorbed into the expanding polity of Snorri Sturluson, who consolidated power over the Borgarfjörður district and, around 1205, removed Gilsbakki's dynasty (the Gilsbekkingar) from power. The farm continued to be an important and wealthy regional estate and ecclesiastic centre until 1907, when its church - founded most likely in the eleventh century - was decommissioned. Gilsbakki is still occupied, but unlike many former elite sites in Iceland, Gilsbakki's retraction from its early role as a regional political centre has made it something of a backwater today. As a result, the farm was not subjected to extensive construction in the twentieth century and contains deeply stratified cultural deposits that are well preserved over the central core of the farm mound. Two trial trenches were excavated at the site in 2008 and 2009. Trench 1 was placed on top of a deeply stratified midden where the majority of the textiles were found, while Trench 2 appears to have been located on top of, and adjacent to, the foundations of turf ruins from one or more of the site's medieval farmhouses. ${ }^{44}$

Textiles were found in damp deposits, as is frequently the case in Iceland, encased between layers of turf blocks from the demolition of turf houses, where acidic environments favourable for textile preservation were found. A total of 126 fragments of textiles were found at the site; these were analysed by Margaret Ordonez, from the University of Rhode Island, and the author.

Compared to both Stóra-Borg and Reykholt, imported items of cloth were very infrequently recovered at Gilsbakki (Table 2). Two items of felt were recovered, as well as one $2 / 1$ twill and one very fine tabby, but all were in deposits quite late for the Hanseatic period. Yet despite the absence of textiles, Gilsbakki clearly had access to the material culture of German and Hanseatic trade. Pottery of German, Dutch, and Southern Scandinavian origin first appear at Gilsbakki around 1490 and 1520, but become more common after 1550, along with other items of dress and consumption from this same region. ${ }^{45}$ Rather than a passive acquisition of Hanseatic material culture, Kevin Smith suggests that the appearance of this 'Germanic' assemblage at Gilsbakki may reflect conscious efforts by the site's priests to adopt visual symbols and personal accoutrements (redware and stoneware ceramics, leather-heeled shoes, enamelled bronze knife handle, lead pistol shot, early clay tobacco pipes, etc.) that expressed their alliance with the Protestant movement and emulated the possessions of Lutheran bishops and administrators sent to Iceland after the tumultuous decades of the Reformation and during the subsequent century-and-a-half in which the Crown consolidated power, confiscated ecclesiastic properties, and executed heretics. ${ }^{46}$ While the numbers of these objects were relatively few, they almost completely replaced earlier forms of material culture at the site and seem to have been highly valued, as many were quite old when they entered the archaeological record, repaired and kept in use for over 150 years. ${ }^{47}$ What is important to note about this, in the context of this examination, is that the range of imports at Gilsbakki clearly show the site's strong linkages to international trade through the Hanseatic period; yet the site's textile assemblage, unlike those from Reykholt and Stóra-Borg, consists almost entirely of locally woven homespun.

There may be more than one reason for this discrepancy between Gilsbakki's textile assemblage and those of the other two sites, as well as between its 'German' material culture and its indigenous cloth profile. Gilsbakki was an ecclesiastic centre and people may have felt that forms of material culture other than textiles were better suited for signalling their status within the emerging 'German' or 'Lutheran' social environment. However, it may also be that as Gilsbakki was an ecclesiastic centre its households were inclined to adhere more closely to the conservative sumptuary laws that were present across Europe at the time. Sweden had many such laws in place, particularly during the sixteenth and seventeenth centuries, that asserted dangerous influences stemming from foreign textile goods and accused foreign merchants of introducing dangerous new fashions that undermined existing, traditional dress styles. Women were particularly targeted in these laws. ${ }^{48}$ Similarly conservative concerns regarding dress may have been present at Gilsbakki, as the limited discussion of sumptuary laws in Iceland's postmedieval law code, Jónsbók cautioned Icelanders about the 'objectionable practices which men have taken into custom' regarding 'fancy' dress. ${ }^{49}$ Jónsbók warned of the dangers of adopting new, frivolous styles of dress which could result in large debts or in people freezing to death. ${ }^{50}$ Therefore strict guidelines were imposed on people according to their wealth: '... anyone who has twenty hundreds and not less, whether he is married or not, may wear a jacket with a hood made of costly material; and whoever has forty hundred may wear in addition a tunic made of costly material; whoever has eighty hundreds may wear in addition a coat or a cloak 
Fig. 5. Possible imported textile found at StóraBorg (photo: Hayeur Smith).

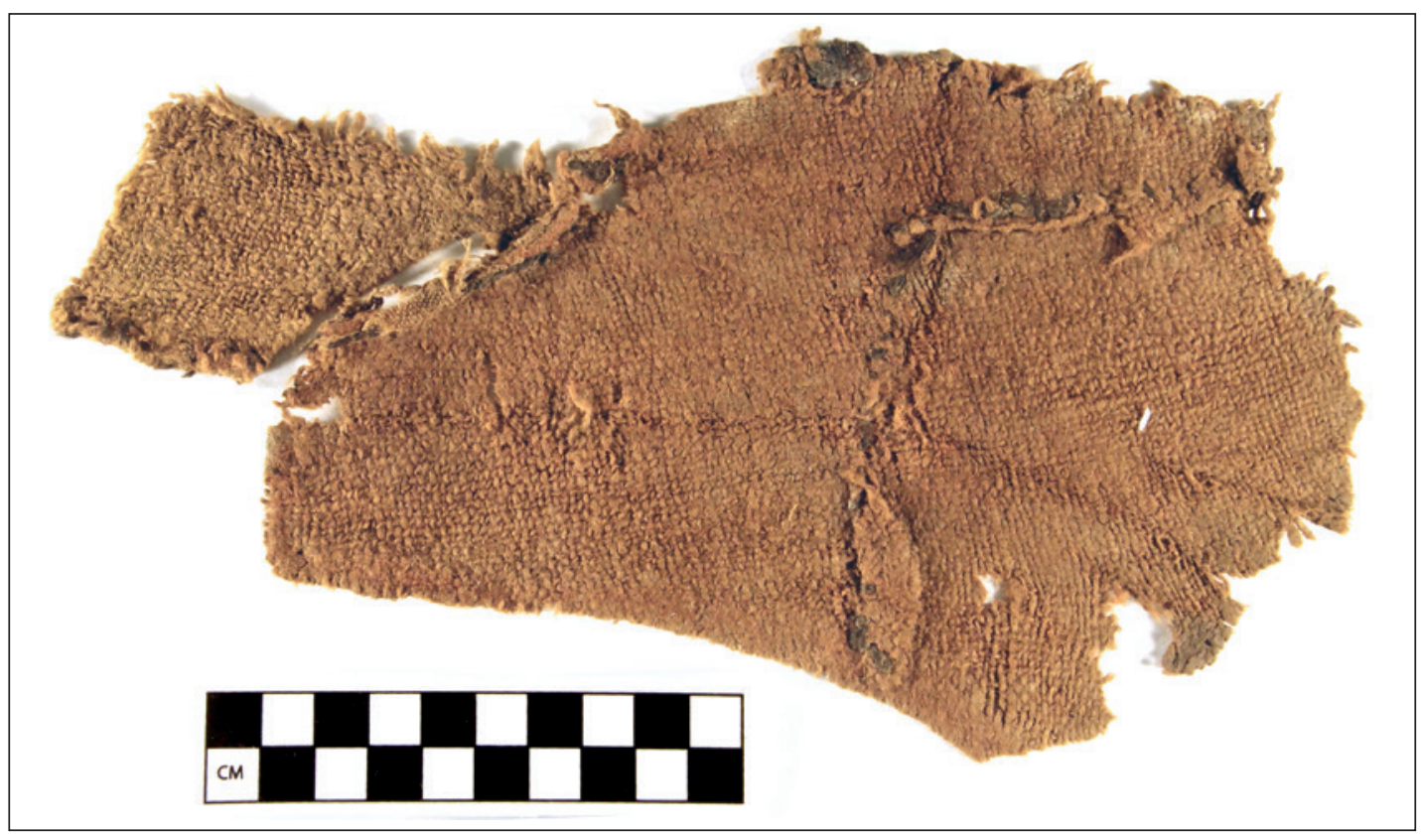

with a hood double lined, yet not with grey fur; whoever has one hundred hundreds, he may wear freely all of this clothing, except learned men may wear whatever clothing they wish as may the king's retainers who have all the weapons which they are required to have. And those men who have travelled abroad are allowed to wear the clothing which they themselves bring back while they last, even if they have less property that what was said before, but they shall not buy more clothing than was stipulated before. But if someone wears finery who has less property or otherwise than here is indicated then he is fined two ounce units for each piece of clothing he wears beyond what the law indicated, unless the clothing is given to him. ${ }^{51}$

These laws clearly limited the use of 'costly materials' and imported clothes to the uppermost echelons of medieval and post-medieval Icelandic society, as twenty hundreds was the value of twenty cattle, 120 sheep, or a moderate-sized, 'independent' (i.e. non-tenant) farm. While Gilsbakki's Hanseatic era residents may have simply wanted to respect these conservative sumptuary laws, the farm's wealth would most likely have exempted its core household members from the sorts of restrictions that Jónsbók prescribes, and this behaviour seems to contradict the consipicuous display of other forms of imported material culture that make this period stand out in the site's archaeological record.

Other explanations for the lack of foreign cloth at Gilsbakki may involve the geographic location of this site and its distance from the sea. Geographically, both Gilsbakki and Reykholt are located quite far inland, while Stóra-Borg sits directly onshore. Gilsbakki
Table 2. Percentage of foreign imports per site (Hayeur Smith 2012a; Hayeur Smith 2012b; Hayeur Smith 2013; Hayeur Smith 2014a; Hayeur Smith 2014b; Hayeur Smith 2015; Hayeur Smith 2016).

\begin{tabular}{|l|c|c|}
\hline $\begin{array}{l}\text { Storaborg sample of } 151 \\
\text { numbers }-300 \text { items of } \\
\text { cloth analyzed } \\
\text { (total amount of cloth } \\
\text { fragments estimated at } \\
1000)\end{array}$ & $\begin{array}{l}\text { Reykholt Church and Farm } \\
\text { 526 fragments of cloth } \\
\text { analyzed. }\end{array}$ & $\begin{array}{l}\text { Gilsbakki - from } 2 \text { sample } \\
\text { trenches. } \\
\text { analyzed } \\
\text { (32 (2008) }+94(2009))\end{array}$ \\
\hline $\begin{array}{l}33 \text { items of foreign cloth } \\
11 \%\end{array}$ & 38 items of foreign cloth \\
\hline
\end{tabular}

and Reykholt, which were both elite farms, had such an abundance of grazing land for their sheep that they may have had no need for foreign cloth, except to denote status in some circumstances - as seems to be the case at Reykholt, where worsteds, satin-finished twills, and silk were present, even though not in abundance. Textile debris, distaff fragments, spinners' discarded work, etc., are also abundant at both of these sites, suggesting that they may have produced more than enough cloth for their own needs and were producers of textiles for export rather than importers, focusing their efforts on acquiring imports and more visible items of material culture for their households and personal use to denote and emulate specific German, Hanseatic and northern European associations.

Finally, the differential representation of imported cloth at Gilsbakki and Reykholt may reflect differences in the trajectories of these parish farms within the social and economic lives of their district. While Reykholt's parish expanded throughout the post-Reformation period and it retained its role as a regional 


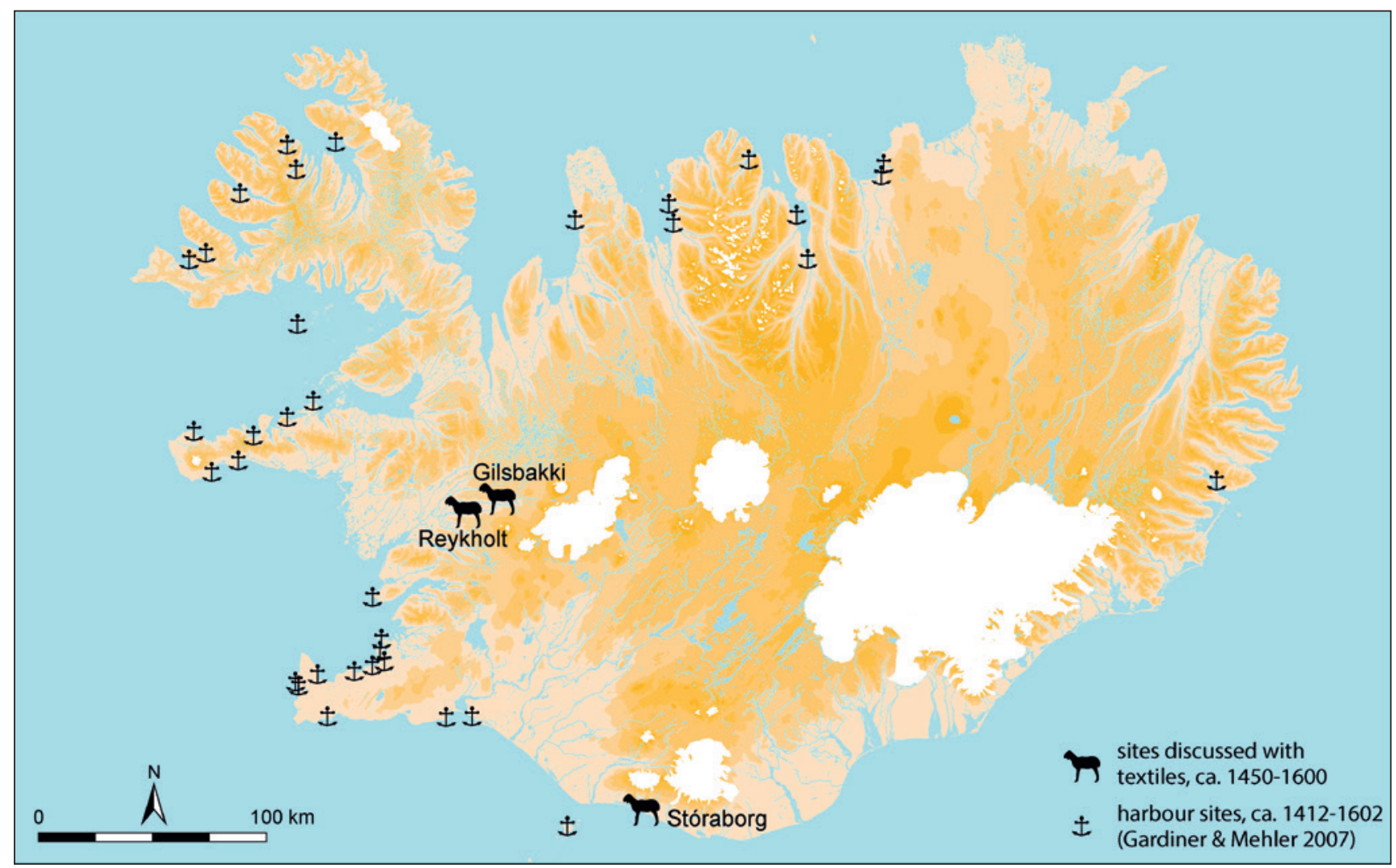

Fig. 6. Map of Iceland with the location of the sites discussed (illustration: Joris Coolen).

and national cultural center, Gilsbakki slowly slipped into a lower rank within the ecclesiastic and political structure of rural western Iceland. Until 1605, for example, farmers on the southern side of the river Hvitá, in the commune of Hálsasveit, were required to bring their dead to Gilsbakki for burial as they had done since at least the thirteenth century. However, after 1605, the community buried its dead at a smaller church on Stóri-Âs, one of its farms, and this became a part of the parish of Reykholt. Thus, as Reykholt's role expanded, Gilsbakk's status declined and although its household acquired and consumed smaller material goods acquired through trade with the Hanse, it may be that any foreign cloth its household members acquired were too valuable to discard, rework, or consign to the archaeological record in the same numbers that a wealthier farm, like Reykholt, could afford. At the same time, Gilsbakki owned far more local grazing land than Reykholt. The ready availability of woollen cloth from its own flocks and those of its tenant farms may have made using local textiles a reasonable compromise that, perhaps, also signaled some assertions of tradition and Icelandic values, while at the same time the use of imported Hanseatic status symbols, such as tablewares, beverages, and personal items may have signaled this land-rich but lower-ranked parish farm's households' allegiance to the new Lutheran ecclesiastic structure and its privilege relative to its parishioners.

Stóra-Borg, however, had little grazing land. Based on the site's archaeofaunal assemblage of more than 100,000 identifiable fragments, the farm always appears to have been engaged in large-scale fishing. ${ }^{52}$ The large number of tabby weaves of foreign origin at this site is, therefore, striking and suggests the possibility that Stóra-Borg's inhabitants may have been engaged in trading their dried fish (skreið) at the harbours of Eyarbakki and the Westman Islands for cloth and other goods, as Mjöll Snaesdóttir has suggested (Fig. 6). ${ }^{53}$

A remarkable number of cloth seals has, in fact, been recovered from the southern coast of Iceland in the vicinity of Stóra-Borg and these may offer additional insights regarding the disproportionate numbers of cloth imports from the fifteenth to seventeenth century layers at this site. These seals' iconography and inscriptions are not always easily identifiable, and they are infrequently found in Iceland; but they have been recovered from Bessastaðir (the colonial governors' estate near Reykjavík), Skálholt (the southern bishopric located in south-western Iceland); at the wealthy parish farm of Reykholt, and at Stóra-Borg, a relatively smaller farm where, paradoxically, relatively large numbers of these seals are recorded. 
Cloth seals were used in ways comparable to the placement of hallmarks on precious metals, and were put on saleable cloth to verify its quality and origins. ${ }^{54}$ Usually, these cloth seals were attached to bales of cloth rather than individual bolts of fabric, although not on the outside of the bale itself as is frequently assumed. ${ }^{55}$ In some instances, they were placed on cloth before it had undergone any finishing treatment such as fulling or dyeing ${ }^{56}$ to identify the factory or workshop where the cloth was made or to register the taxes or duties already paid on it.

Several cloth seals have been found in and around Stóra-Borg. The most legible of them was found in the excavation of the same rooms that produced the probable imports dating to the Hanse period. This seal has a heraldic lion carrying a staff on one side and the initials VL on the back. The inclusion of Roman numerals could indicate the weight of the parcel in pounds or the alnage officer's privy mark..$^{57}$ A cloth seal from Skálholt has a similar VL on one side suggesting that both of these may have come on cloth shipped from the same area in Europe.

The Stóra-Borg seal was dated to the seventeenth century by Pórlaksson who concluded that it was German. ${ }^{58}$ No parallels are known in comparative data from Britain or Bremen. ${ }^{59}$ Fourteen seals have been found, in total, at Stóra-Borg and from the sands along the coast near Stóra-Borg, where Pórður Tómasson, curator of the Skógar Folk Museum, has collected them after storms battered the farm mound at Stóra-Borg and several smaller, nearby sites. Most of these no longer have any inscriptions, or are highly corroded fragments, with the exception of one from Sanhólmagjá on display at the Skógar museum, which appears to have the obscure inscription 'fordh norlic'. Although it is thought to date to the sixteenth century, no European comparisons or comparable inscriptions have yet been identified.

Despite our current inability to identify their specific countries of origin, the diversity and number of cloth seals recovered from this small region suggest that its households, especially at Stóra-Borg, were involved in a complex pattern of trade networks. While the author is clearly not arguing that Stóra-Borg was a central trade centre for Iceland, the available data clearly suggest that this coastal area had more access to foreign textile products in bulk quantities than did more inland sites such as Reykholt and Gilsbakki. If bales and cloth were fitted with seals, the bails presumably had to be broken up into smaller units of cloth before they could be used or resold through local trade. The numerous cloth seals found in and around Stóra-Borg might suggest that during the Hanseatic period StóraBorg, a wealthy farm but not a parish centre, played a pivotal role in the regional redistribution of cloth and other goods obtained in exchange for fish. Perhaps the farmer at Stóra-Borg acted as a middle-man, during and after the Hanseatic period collecting fish from neighbouring farms, and in return distributing items of trade such as cloth. This may explain the abundance and diversity of textile activity evident in rooms 9 and 14 of the site's second phase, in room 18 of Phase 3 , and in the deposits between them. It was also in this area, in deposits of Phase $2 / 3$, that the cloth seal was found.

A similar model of a 'coastal market place' as suggested here for Stóra-Borg was discussed by Callow regarding the earlier medieval site of Dögurðarnes in Western Iceland. Callow's research involved an indepth analysis of written sources regarding the region, and concluded that smaller sites such as Dögurðarnes may have acted as a sort of small market, and distribution centre outside the control of chieftains, with more imported objects reaching a greater audience than previously expected. ${ }^{60}$

\section{Conclusion}

It is worth asking whether the 'foreign cloth' from these sites represents Hanseatic trade, and especially whether the presence of English or German cloth in sixteenth-century deposits at these sites represents products carried in Hanseatic merchants' vessels? It seems most likely that they were, or could have been, given the Hanseatic merchants' dominant role in Iceland's trade and also their active efforts to transship English cloth as a preferred item of cargo. But could it be that the turbulent upheavals of the Reformation, which were taking place during that same hundredyear period, combined with the eventual triumph of Lutheranism in Iceland, described as 'brought on by force' and 'not welcomed by the Icelandic people" ${ }^{61}$ drove the Icelanders - particularly on elite ecclesiastic farms where they were under constant threat of having their land seized - to embrace whole-heartedly material culture stemming from the Lutheran countries? ${ }^{32}$

Material culture, in this case, becomes a symbolic visual manifestation of the victors in a religious and political struggle that raised the Danish monarchy's authority to rule by divine right rather than papal authority, and eventually made the Crown Iceland's biggest land-holder. By 'consuming' their material culture, centres such as Gilsbakki may have been conveying public messages of acceptance of the new faith 
and the new order, thus avoiding confrontation. The pottery at Gilsbakki seems to hint to this, but textiles from this site tell us nothing. In fact, neither do those from Stóra-Borg or Reykholt, other than that at one site they consumed ordinary European woollens and at the other finer imported cloth. If the adoption of 'Hanseatic material culture' represents an active act of messaging and identity-formation by consumers, rather than simply passive acquisition of what merchants made available to them, this is surprising, as dress and visual appearance are among the more effective ways of displaying cultural identity and a sense of 'belonging' or conformation. Furthermore, dress styles changed drastically at the time of the Reformation in Iceland and one would think that people would seek out foreign cloth more fitting of European Lutheran dress practices of the time in order to do so. Or, perhaps some Icelanders chose to ignore them by actively declining these goods, demonstrating humility, making visual statements about local identity, facing economic realities, or signalling adherence to both the sumptuary laws of the period and the more austere values of the new religious ideal.

The sixteenth century was a period of intense political and social upheaval in Iceland, as elsewhere in northern Europe. Is it possible that dress practices were one of the last things to change? By continuing to produce Icelandic homespun - something that had been such an important commodity for centuries - on farms that could afford to do so, people may have been expressing a discrete form of resistance to change, to direct colonial rule, or the new faith by not changing their styles of dress immediately and only doing so when they no longer had the choice.

\section{Acknowledgements}

This research was made possibly with funds from the National Science Foundation, Arctic Social Sciences, Polar Programs Award no. 1023167, and Award no. 1303898 and with the help from the following institutions: Haffenreffer Museum of Anthropology, Brown University; the National Museum of Iceland; Fornleifastofnun Îslands. I would also like to thank the following individuals: Kevin P. Smith for his help and insights into the site of Gilsbakki, Mjöll Snæsdóttir for her insights into Stóra-Borg, Guðrun Sveinbjarnardóttir, Gavin Lucas, Lilja Arnádottir, and the curatorial staff at the National Museum of Iceland as well as Natascha Mehler, and Mark Gardiner for inviting me to the Hanseatic trade in the North Atlantic conference.

\section{Endnotes}

${ }^{1}$ Gjerset 1924; Karlsson 2000, 123-27.

${ }^{2}$ Robertsdóttir 2008.

${ }^{3}$ Friedland 1983, 86-95.

${ }^{4}$ Guðjónsson 1962; Guðjónsson 1965; Guðjónsson 1970; Guðjónsson 1973; Guðjónsson 1972; Guðjónsson 1998a; Guðjónsson 1988b; Guðjónsson 1996, 97; Guðjónsson 1992; Guðjónsson 1994.

${ }^{5}$ Guðjonsson 1962; Hoffmann 1974; Walton Rogers, in Sveinbjarnardóttir 2012.

${ }^{6}$ Hayeur Smith 2012a; Hayeur Smith 2012b; Hayeur Smith 2013; Hayeur Smith 2014a; Hayeur Smith 2014b; Hayeur Smith 2015; Hayeur Smith 2018.

${ }^{7}$ Hoffmann 1974; Porláksson 1991; Hayeur Smith 2012a; Hayeur Smith 2014a; Hayeur Smith 2015.

${ }^{8}$ Hayeur Smith 2014a, 731.

${ }^{9}$ Mehler 2009, 98.

${ }^{10}$ Ibid.

${ }^{11}$ Gjerset 1924.

${ }^{12}$ Karlsson 2000, 124.

${ }^{13}$ Ibid., 126; Mehler and Gardiner 2013, 403.

${ }^{14}$ Gjerset 1924, 274; Karlsson 2000, 124; Mehler and Gardiner 2013, 403.

${ }^{15}$ Kijavainen 2009, 93.

${ }^{16}$ Ibid.

${ }^{17}$ Maik 2009; Munro 2003.

${ }^{18}$ Egen 1987.

${ }^{19}$ S. Peachy, personal communication, 2013.

${ }^{20}$ Walton Rogers 2012.

${ }^{21}$ 2010-2013: Rags to Riches: An Archaeological Study of Textiles and Gender in Iceland, AD 874-1800 (NSF Award no. 1023167) PI. M. Hayeur Smith; 2013-2016: Weaving Islands of Cloth: Gender, Textiles, and Trade Across the North Atlantic from the Viking Age to the Early Modern Period (NSF Award no. 1303898), PI. M. Hayeur Smith.

${ }^{22}$ Ordoñez 2012.

${ }^{23}$ Sinding et al. (in press).

${ }^{24}$ Frei 2014.

${ }^{25}$ Garðarsdóttir 2010.

${ }^{26}$ Maik 2009.

${ }^{27}$ Hayeur Smith 2012; Hayeur Smith 2013; Hayeur Smith 2014a; Hayeur Smith 2018.

${ }^{28}$ Minar 2001, 382.

${ }^{29}$ Hayeur Smith 2012a; Hayeur Smith 2013; Hayeur Smith 2014a; Hayeur Smith 2015; Hayeur Smith 2018.

${ }^{30}$ Hoffmann 1974; Bender Jørgensen 1992; Robertsdóttir 2008; Bek Pedersen 2007; Bek Pedersen 2009; Andersson Strand 2012; Hayeur Smith 2014a.

${ }^{31}$ sensu Gullbeck 2011; Hayeur Smith 2014a, 731.

${ }^{32}$ Milek 2012; Bek Pedersen 2009.

${ }^{33}$ Cleasby et al. 1957; Hayeur Smith 2012; Hayeur Smith 2014a.

${ }^{34}$ Hayeur Smith 2014a.

${ }^{35}$ Snaesdóttir 1991.

${ }^{36}$ Snaesdóttir, personal communication, 2013.

${ }^{37}$ Walton Rogers, in Sveinbjaranardóttir 2012.

${ }^{38}$ Maik 2009.

${ }^{39}$ Sveinbjarnardóttir 2006.

${ }^{40}$ Walton Rogers 2012.

${ }^{41}$ Ibid.; Hayeur Smith 2018. 
42 Tidow and Jordan-Fahrbach 2007.

${ }^{43}$ Walton Rogers 2012.

${ }^{44}$ Smith 2009.

${ }^{45}$ Ceramic identifications from Gilsbakki were done by Etel Colic at Fornleifastofnun Íslands, 2010.

${ }^{46}$ Kevin Smith, personal communication, 2013.

${ }^{47}$ Smith 2009.

${ }^{48}$ Andersson Strand 2014.

${ }^{49}$ Jónsbók, 153.

${ }^{50}$ Ibid.

${ }^{51}$ Ibid.

${ }^{52}$ McGovern 1990.

${ }^{53}$ Personal communication, 2013.

${ }^{54}$ Egan 1987.

${ }^{55}$ Ibid.

${ }^{56}$ Ibid.

${ }^{57}$ Ibid.

${ }^{58}$ Porláksson 2010, 144

${ }^{59}$ Egan 1987; Hittinger 2008.

${ }^{60}$ Callow 2010, 213-29.

${ }^{61}$ Hjálmarsson 1993.

${ }^{62}$ Kevin Smith, personal communication.

\section{References}

Printed sources (see also list of abbreviations)

Jónsbók, The Laws of Later Iceland, The Icelandic text according to MS AM351 fol. Skálholtsbók eldri, ed. by J. K. Schulman. Saarbrücken: AQ-Verlag, 2010.

\section{Secondary literature}

Andersson Strand, E. 2012. Tool and textiles, production and organization in Birka and Hedeby, in S. Sigmundsson (ed.), The Viking Settlements and Viking Society: Papers from the Proceedings of the Sixteenth Viking Congress, Reykjavik and Reykholt 16th-23rd August 2009, 1-17. Reykjavík: University of Iceland Press.

Andersson Strand, E. 2014. Foreign sanctions: sumptuary laws, consumption and national identity, in early modern Sweden, in T.E. Mathiassen, M.L Nosch, M. Ringgaard, K. Toftegaard, and M. Venborg Pedersen (eds), Fashionable Encounters, Perspectives and Trends in Textile and Dress in the Early Modern Nordic World, 17-27. Oxford: Oxbow Books.

Bek Pedersen, K. 2007. Are the spinning nornir just a yarn?, Viking and Medieval Scandinavia 3, 1-10.

Bek Pedersen, K. 2009. Weaving swords and rolling heads: a peculiar space in Old Norse tradition. Viking and Medieval Scandinavia 5, 23-39.

Bender Jørgensen, E. 1992. North European Textiles until AD 1000. Aarhus: Aarhus University Press.

Callow, C. 2010. Iceland's medieval coastal market places: Dögurðarnes in its economic, social and political context, in J. Brendalsmo, T. Gansum and F.-E. Eliassen (eds), Strandsteder, utvikinglingssteder og småbyer $i$ vikingtid, middelalder og tidlig nytid (ca. 800-ca. 1800), 213-229. Oslo: Interface Media.

Cleasby R. Vigfusson, G. and Craigie, W. 1957. An IcelandicEnglish Dictionary. Oxford: Clarendon Press.
Egan, G. 1987. Provenanced Leaden Cloth Seals. Unpublished PhD thesis. University of London.

Frei, K.M. 2014. Strontium isotope analyses of ancient wool thread samples from Viking Age to Early Modern retrieved from Iceland. National Museum of Denmark. Unpublished report.

Friedland, K. 1983. Hanseatic merchants and their trade with Shetland, in D.J. Withrington (ed.), Shetland and the Outside World, 86-106. Oxford: University of Aberdeen.

Garðarsdóttir, V. 2010. Alpingisreiturinn, vol. 1 and 2. Unpublished excavation report, Reykjavík.

Gjerset, K. 1924. History of Iceland. New York: The MacMillan Company.

Gullbeck, S. H. 2011. Norway: commodity money, silver and coins, in J. Graham-Campbell, S. M. Sindbæk and G. Williams (eds), Silver Economies, Monetization and Society in Scandinavia AD 800-1100, 93-111. Aarhus: Aarhus University Press.

Guðjónsson, E. 1962. Forn röggvarvefnaður. Árbók hins islenzka Fornleifafélags 1962, 12-71.

Guðjónsson, E. 1965. Um skinnsaum, Árbók hins íslenzka Fornleifafélags 1964, 69-87.

Guðjónsson, E. 1970. The National Costume of Women in Iceland. Reykjavik: Litbrá.

Guðjónsson, E. 1973. Íslenzk útsaumsheiti og útsaumsgerdir á miðöldum. Árbók hins íslenzka Fornleifafélags 1972, 131-150.

Guðjónsson, E. 1998a. Kljásteinavefstaðir á Íslandi og á Grænlandi, Árbók hins íslenzka Fornleifafélags 1996-97, 95-120.

Guðjónsson, E. 1998b. Um vefstóla á Íslandi á 18. öld. Nokkrar athugasemdir. Árbók hins íslenzka Fornleifafélags 199697, 129-140.

Guðjónsson, E. 1992. Um rokka, einkum med tilliti til skotrokka, Árbók hins íslenzka Fornleifafélags 1992, 11-52.

Guðjónsson, E. 1994. Um vefstóla og vefara á Íslandi á 18. og 19. öld. Árbók hins islenzka Fornleifafélags 1993, 5-50.

Hayeur Smith, M. 2012a. Some in rags, some in jags and some in silken gowns: textiles from Iceland's early modern period. International Journal of Historical Archaeology 16(3), 509-528.

Hayeur Smith, M. 2012b. The Heddle Rods Are Blood-Soaked Spears: Life, Death, Fate, and Female Embodiment through Weaving in Viking Age and Medieval Iceland. Paper presented at the 2012 Annual Meeting of the American Anthropological Association, San Francisco, 14-18 November.

Hayeur Smith, M. 2013. The textile collection from the 1988 Bessastaðir excavation, in G. Ólafsson (ed.), Bessastaðarannsókn II. Kikjugarður og Miðaldaminjar Uppgraftarsvæði 12-15, 93-110. Reykjavík: Skýrslur pjóðminjasafn Îslands.

Hayeur Smith, M. 2014a. Thorir's bargain: vaðmál, gender and the law. World Archaeology 45, 730-746.

Hayeur Smith, M. 2014b. Dress, cloth and the farmer's wife: textiles from $\varnothing 172$ Tatsipataa, Greenland with comparative data from Iceland. Journal of the North Atlantic 6, 64-81.

Hayeur Smith, M. 2015. Weaving wealth: cloth and trade in viking age and medieval Iceland, in A. L. Huang and 
C. Jahnke (eds), Textiles and the Medieval Economy, Production, Trade and Consumption of Textiles 8th-16th Centuries, 23-40. Oxford: Oxbow Books.

Hayeur Smith, M. 2018. Vaðmál and Cloth Currency in Viking Age and Medieval Iceland, in J. Kershaw, G. Williams and S. Sinbaek (eds), Silver, Butter, Copper, Cloth: Currencies and Value in the Viking Age, 251-277. Oxford: Oxford University Press

Hittinger, D. 2008. Auswertung der Tuchplombenfunde der Teerhofgrabung. Bremer Archäologische Blätter 7, 111-144.

Hjálmarsson, J. R. 1993. History of Iceland: from the Settlement to the Present Day. Reykjavík: Iceland Review.

Hoffmann, M. 1974. The Warp-Weighted Loom: Studies in the History and Technology of an Ancient Implement. Oslo: Hestholms Boktrykkeri.

Karlsson, G. 2000. Iceland's 1100 Years, the History of a Marginal Society. London: Hurst \& Company.

Kirjavainen, H. 2009. A Finnish archaeological perspective on medieval broadcloth, in K. Vestergård Pedersen and M. L. Nosch (eds), The Medieval Broadcloth, 90-99. Oxford: Oxbow Books.

Maik, J. 2009. The Influence of Hanseatic trade on textile production in medieval Poland, in K. Vestergård Pedersen and M. L. Nosch (eds), The Medieval Broadcloth, 109-122. Oxford: Oxbow Books.

McGovern, T. 1990. The archaeology of the Norse North Atlantic. Annual Review of Anthropology 19, 331-351.

Mehler, N. 2009. The perception and interpretation of Hanseatic material culture in the North Atlantic: problems and suggestions. Journal of the North Atlantic, Special Volume 1, 89-108.

Mehler, N. and Gardiner, M. 2013. On the Verge of colonialism, English and Hanseatic trade in the North Atlantic islands, in P. E. Pope and S. Lewis-Simpson (eds), Exploring Atlantic Traditions, 1-14. Woodbridge: The Boydell Press.

Milek, K. 2012. The role of pit houses and gendered spaces on Viking Age farmsteads in Iceland. Medieval Archaeology $56,85-130$.

Minar. J. 2001. Motor skills and the learning process: the conservation of cordage final twist direction in communities of practice. Journal of Anthropological Research 57(4), 381-405.
Munro, J. 2003. Medieval woollens: textiles, technology, and industrial organisation, $c$. 800-1500, in D. Jenkins (ed.), Cambridge History of Western Textiles I, 181-227. Cambridge: Cambridge University Press.

Ordoñez, M.T. 2012. Reykholt Textile Analysis Report. Unpublished Textile Report, University of Rhode Island, Department of Textiles, Design and Fashion Merchandising, Rhode Island.

Robertsdóttir, H. 2008. Wool and Society: Manufacturing Policy, Economic Thought and Local Production in 18thCentury Iceland. Göteborg: Makadam.

Sinding, M., Vieira, F. and Hayeur Smith, M. 2017, Unmatched DNA preservation prove arctic hare and sheep wool in Norse Greenland textile from 'The Farm Beneath the Sand'. Journal of Archaeological Science: Reports, 14, 603-608.

Smith, K. P. 2009. Preliminary Investigations at Gilsbakki, Borgarbyggð, Western Iceland: 2008 Season. Unpublished report, Haffenreffer Museum of Anthropology, Brown University, Providence RI.

Snæsdóttir, M. 1991. Stóra-Borg Fornleifarannsókn 1978 1990. Reykjavík: Pjóðminjasafn Íslands.

Sveinbjarnardóttir, G. 2006. Reykholt: A centre of power. the archaeological evidence, in E. Mundal (ed.), Reykholt som makt- og laerdomssenter $i$ den islandsk og nordiske kontekst, 25-42. Reykholt: Snorrastofa.

Sveinbjarnardóttir, G. 2012. Reykholt: Archaeological Investigations at a High Status Farm in Western Iceland. Reykjavík: National Museum of Iceland.

Porláksson, H. 1991. Vaðmál og verðlag. Vaðmál í utanlandsviðskiptum og búskap Íslendinga á 13. og 14. öld. Reykjavík: Heimspekideild Háskóla Îslands.

Porláksson, H. 2010. Saga Íslands, vol. 6. Reykjavík: Sögufélag.

Tidow, K. and Jordan-Fahrbach, E. 2007. Woollen textiles in archaeological finds and descriptions in written sources $\mathrm{f}$ the 14th to the 18th centuries, in C. Gillis and M.L. Nosch (eds), Ancient Textiles, Production, Craft and Society, Proceedings of the Frist International Conference on Ancient Textiles held at Lund, Sweden, Copenhagen, Denmark on March 19-23, 2003, 97-103. Oxford: Oxbow Books.

Walton Rogers, P. 2012. Textiles, wool and hair, in G. Sveinbjarnardóttir (ed.), Reykholt: Archaeological Investigations at a High Status Farm in Western Iceland, 196-217. Reykjavík: National Museum of Iceland. 